\title{
'I am who I am': Deconstructing orphaned boys' references to God: An application of the post- foundational notion of practical theology
}

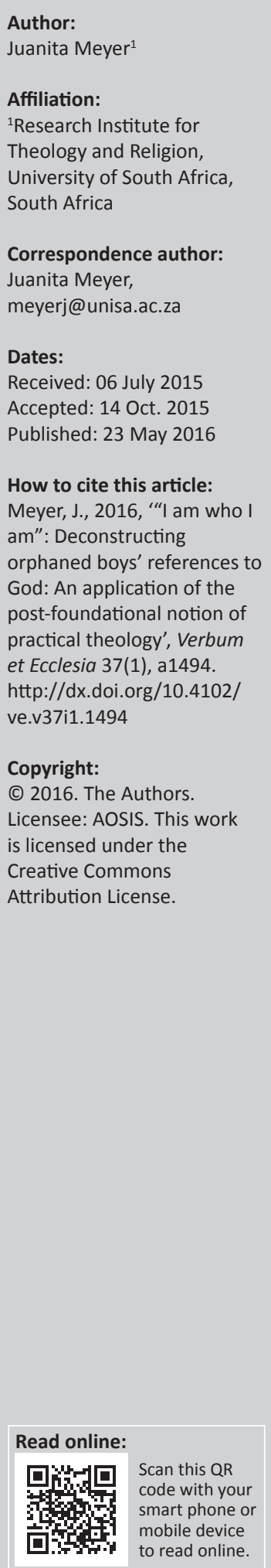

This article investigates and reflects on the religious and spiritual aspects inherent in the narratives of adolescent male orphans, affected by HIV and AIDS, poverty and fatherlessness, and more specifically on aspects which tell us about how these boys understand and experience the presence of God within their specific situations. In coming to such an understanding, this article focuses specifically on the various names attributed to God by the coresearchers and investigates the prominence through social construction behind these names and how it influences the coresearchers' experience of God amidst their unique circumstances. With the use of the perspectives of a post-foundational notion of practical theology and narrative therapy and research, these names and their accompanied significance are deconstructed. The aim of the deconstruction process is to unveil dominant discourses that both inform the use of specific references to God and assist the coresearchers in finding meaning in the use of these names. The larger study employed research methods from the qualitative and case study research design, and included interdisciplinary work based on the post-foundational notion of transversality. Disciplines included in the dialogue were pastoral therapy, critical psychology and social work. This article's reflections can be useful in all the above-mentioned disciplines and gives insight into understanding the significance behind the phenomenon of naming a deity in one's personal and public language, and the influence such spiritual affirmations have in the psychosocial sphere of the holistic persona.

Intradisciplinary and/or interdisciplinary implications: The larger study (from which this article originates) is an interdisciplinary study, as to conform to the principles of a postfoundational notion of practical theology and as such supports the assumptions underlying this theoretical framework.

\section{Background to the research}

This article originates from the broader study titled, The spiritual and psychosocial gender specific stories of adolescent orphans affected by HIV and AIDS, in the absence of a Father Figure (see Loubser 2010). The aim of the study was to dissect the life experiences of boys who were orphaned, in the midst of HIV and AIDS and investigate how these experiences influence his sexual and power relations with women and his role as future father and husband, in the absence of a father figure. One objective was to explore the various ways in which these past and future narratives influence or affect the male orphan's view of and relationship with God, or to investigate the converse; how his view of and relationship with God influence and affect his relationship with his past narrative and development of his future narrative. This study was conducted within the epistemological and methodological frameworks of qualitative postmodern and post-foundational research based on the models of the narrative approach and the seven movements of a post-foundational ${ }^{1}$ notion of practical theology.

\footnotetext{
1.Postfoundationalism is described by van Huyssteen (1999:3) as a refiguration of the notion of rationality. This refiguration assists the practical theologian to come to a better understanding of the different epistemological and hermeneutic concerns and to discover the value inherent in a variety of resources born from different domains of knowledge. With the use of responsible, critical judgement and discernment, the theologian adopts an attitude of inclusion and non-judgement. A post-foundational notion of practical theology thus enables a researcher to be open and sensitive to the context, as to be unbiased in listening to specific cues in discourses. This will enable the theologian to be sensitive and descriptive in the deconstruction of problematic discourses, as well as in its development of alternative discourses or narratives (cf. Müller 2005:86). Van Huyssteen (1999) postulates that this type of theological reflection will circle around three specific movements: firstly, the role of contextuality and interpreted experiences; the influence of disciplinary tradition in the values porence in the world need to be acknowledged (he existemic duty (which extends the boundaries of and boundedness to their specicistive and in reflective and effective interdisciplinary dialogue, so as discovered shared resources are expressed through the notion of transversality that encourages diverse and authentic dialogue around contentious discourses. It creates an opportunity for dynamic and meaningful dialogue that is focussed on true understanding of the phenomenon at hand (Müller 2005:76-77). The emergence of postfoundationalism; thus provided practical theology with the opportunity to enhance its reflective practice by ensuring that the evaluation of its episteme becomes the imperative of practical theology (Müller 2005:73-74). Please refer to the following articles for an in-depth description of the methodology and epistemology used in this study as well as the findings: Loubser and Muller (2011), Meyer (2013a), Meyer (2013b), Meyer (2014).
} 
Seven participants were selected according to non-probability sampling methods, and open-ended interviews and focus group discussions were conducted. At the commencement of the research all the boys, except one, were double orphans and all of them lived in conditions of extreme poverty and were registered with two non-governmental organisations (NGOs) as 'orphaned and vulnerable'. Five of the boys resided in a safe house of the relevant NGO. At the commencement of the study, the boys were between the ages of 15 and 18 years. Three of the boys' narratives were selected and used per illustration in this article.

All of the boys (who are now young men) are from an African ethnic background. All of the boys are religious (confessed Christians) but do not necessarily ascribe to a specific denomination. While in the care of the NGO, they regularly attended the services of a local Dutch Reformed Church. None of the boys were particularly interested in traditional African religious practices at the time, but at the same time none of the boys denied belief in any of these practices. This might be due to the fact that they were brought up by other caregivers, from different cultural and religious backgrounds than their families, after the death of their parents. As a result they were not continuously exposed to traditional African religious practices. Nevertheless, they were in contact with other family members and friends who did participate in traditional African religious practices, indicating perhaps that they must have been influenced, culturally and religiously, if not directly, surely indirectly.

Throughout this article the boys are referred to as coresearchers. This is significant because as coresearchers, they are validated and privileged as experienced, expert participants who are essentially '... collaborators in the process of gathering and interpreting data' (Boylorn 2008:599). This is a participatory method of doing research within qualitative research and crucial to the understanding of the philosophical viewpoints of the broader study (cf. Boylorn 2008:599). At the start of the research the coresearchers $^{2}$ chose pseudo-names for themselves, which have special meaning to them.

\section{Interests of article}

The primary aim of this article is to investigate and reflect on the religious and spiritual aspects inherent in the narratives of the coresearchers and more specifically on aspects which tells us about how these boys understand and experience the presence of God, within their specific situations. In coming to such an understanding, this article focuses specifically on the various names attributed to God by the coresearchers and investigates the prominence through social construction behind these names and how it influences the coresearchers' experience of God amidst their unique circumstances. With the use of the perspectives of a post-foundational notion of practical theology and narrative therapy and research, these names and their accompanied significance are deconstructed.

2.Three coresearchers will be identified as Molimi (meaning 'farmer'), Manqoba (meaning 'victory') and Kgotoso (meaning 'peace').
The aim of the deconstruction process is to unveil dominant discourses that both inform the use of specific references to God and assist the coresearchers in finding meaning in the use of these names.

This article makes extensive use of the concept of deconstruction; therefore a description of the concept is warranted. The first instance of this concept is brought to our attention by the philosopher, Jacques Derrida, who describes it in its essence as a method of reading text ${ }^{3}$. Derrida proposed that any type of reading of text is both possible and accepted, as opposed to the idea that only an expert reader can provide authority to the interpretation of such (cf. Foster 2004:1-8). The imperative of deconstruction is prompted by the notion that text, or discourses carry with it some form of power, which in turn influence the way that we interpret our world and the way that we construct our future (Demasure and Müller 2006:413). As a result deconstruction is employed as a method of exposing these power relations, through the awareness that language itself is the locomotive of constructive power (cf. Foster 2004: 1-8). Consequently, the method of deconstruction is a critical analysis of text or various discourses which shows how certain text imposes certain images and ideas of the world and its relations on its 'readers'. Demasure and Müller (2006:413) postulate that deconstruction is '... concerned with the historical and cultural production of knowledge and how a certain construction contributes to power and social action'.

Therefore, this article's reflections is useful especially for pastoral caregivers as it gives insight into understanding the significance behind the phenomenon of personal naming a deity in one's personal and public language, and the influence such spiritual affirmations have in the psycho-social sphere of the holistic persona. Through the deconstruction process, awareness is created of how the naming of God is influenced by sociocultural and biblical tradition. The inherent value of this for pastoral caregivers and for people consulting a pastoral caregiver lies in understanding the construction of meaning inherent in these practices of naming God and the power of these constructions in enabling or disabling relationship and healing. As will be seen in the next section, the name used to address God says much about the nature of one's understanding of God. When confronted with life's challenges, hurt and cruelty, one is confronted with existential questions, which more than often relates to the perception of God's nature and character. Hence, one's perception of God plays an important role in finding healing after the experience of trauma; an issue faced most often by pastoral counsellors and ministers. People are faced with questions related to 'Who is God?' and 'Who am I to God that God will allow me to hurt in such a way?'. One can either be held captive by one's perception of God, or liberated by being empowered to actively construct an image of and a subsequent relationship with God, which will lead to existential actualisation. Therefore, this article shows the powerful influence of such constructions and its role in permitting positive, constructive and liberating relation.

3.Text in this sense can be any person, event, institution etc 


\section{What is in a name?}

13 Then Moses said to God, 'If I come to the people of Israel and say to them, "The God of your fathers has sent me to you," and they ask me, "What is his name? "what shall I say to them?'

14 God said to Moses, 'I am who I am'. And he said, 'Say this to the people of Israel, "I am has sent me to you." (Exodus 3: 13-15 [ESV])

Exodus 3:13-15 is one of the very first instances found in the Bible in understanding the name of God. What is interesting though are the semantics inherent in the name that God gives to Moses. God says: 'I am who I am'; a word unpronounceable and incomprehensible to the Hebrews of the day (cf. Young 2007). In this section, three things are revealed through God's response to Moses: That God is (1) 'unnameable', (2) that he exists absolutely, (3) that he is an infinite and divine being, who is absolutely free (cf. Young 2007:2). While the semantic dimension of the Name leaves us perplexed and somewhat faint at heart - for shall God not be named then? - the pragmatic dimension, as stated by Philo (cf. Sosckice 2002), reminds us that although God is unique and transcends human language and symbols, God gave this name '... by grace, for our sake, so that we may call on God' (Young 2007:3). Rosenweig and Buber (Buber 1994:104) emphasise the pragmatic dimension of the name by reminding us of God's promise that he will deliver Israel from their suffering. Inherent in the name of God then is the promise of deliverance and liberation, and because Moses received the sign - the symbol - of that promise he becomes the agent of liberation (cf. Young 2007:3; cf. Buber 1994:104).

Exodus 3 shows us then that the names we use to refer to God reveal our subjective understanding of who God is, how God relates to the world, and thereby how we relate to God. Names are signs that people give to one another, that shape relationships, that serve as mediums of communication, which in turn creates possibilities of communion between each other, as a body of believers; and communion with God, as the one who enables communion (cf. Young 2007:1).

Language is the only medium whereby people can represent the Word of God to the world, precisely because what we say about God, and what we name God, matters to ourselves and to others (Braaten 1989:10). Through the different ways in which people name God, people discover new meaning of life and with life through the interpretation of, what Ricoeur (1979:224) calls, 'polyphonic and poetic' references. These references, in turn, open a new world for the person who calls on the name of God (cf. Byrne 2011:51).

Therefore, in probing the reasons behind the specific names that the coresearchers chose to call God - albeit not consciously - we discover how they view God (in other words, the images they attach to God), how they understand God, and how this understanding of God shapes their relationship with God. By looking at the discourses that shape these boys' understanding of God, which lead them to naming God in a specific way, we, as pastoral caregivers, gain some insight into what role we can play in making God more understandable and knowable to believers, as to establish satisfying relationships with God.

\section{Personal references to God}

In this section, specific references to God were extracted from the narratives of the coresearchers ${ }^{4}$. Similar references were grouped together and include the following primary references: (1) God the Father, (2) God the King and (3) God the Shepherd. Underlying each name for God are discourses associated with that reference, deduced from the narratives of the coresearchers. After these discourses are outlined, similar usages of these references from the cultural and religious background of the Bible will be presented. Because of the coresearchers' African heritage, the researcher will also delve into similar notions found in traditional African culture and religion. Finally, all the various discourses will be brought together and deconstructed in the concluding section of this article.

\section{God the Father}

The image of God as Father came up repeatedly during narration and is perhaps the primary way that these coresearchers refer to God.

Protection seems to be one of the primary qualities associated with God as Father. Molimi states that he experiences God as a Father because God looks after him and loves him. He emphasises his trust in God by saying: '[I] am still alive today because of Him'. He states simultaneously that God expects fathers and husbands to protect their families and to love their families because God is this kind of Father himself. Manqoba reiterates this aspect of protection, by stating that God protects, cares for and loves us. He continuously described God's characteristics as loving, caring and protecting, and that God wants the best for him because he is his Father.

Molimi furthermore referred to the guidance that he receives from God, as God is his Father. He was the only coresearcher who attributed guidance to the image of Father. He states that God guides him in '... every way I take'. He furthermore states that in life '... one should obey and trust in God because we should seek him first and everything shall be given on to you'.

For Manqoba, God as Father indicates more than just protection and love, but also that God as Father will discipline as a father does when needed. God as Father loves, protects and guides, but also disciplines as he sees fits. This is a powerful image, as this child in his wisdom understands the difference between discipline and punishment, indicating several distinctive characteristics of God as Father: (1) God as Father is wise and able to discern when the right time is to discipline and (2) A father disciplines out of love for the good of his children.

4.Interviews conducted at a weekend breakaway, from $26-28$ February 2010 , Sikelele Camp site, Magaliesburg. 
Closely related to the discourses of God as Father, but also attached to other images of God, are God's unfailing love for them as their father and that God will provide, because that is what a father does

\section{Discourses related to the name of God as Father in the Old Testament and the New Testament, and Judaic tradition}

In our understanding of the historical biblical use of the name 'Father' for God, we first turn to the cultural norms of Judaism in the Hebrew Bible. In the Hebrew Bible, the name 'Father' is documented in its direct use, referring to $\mathrm{YHWH}$, only twice: once in Isaiah 64:8 and once in Deuteronomy 32:6 (cf. Byrne 2011:130)

These two references in the Hebrew Bible indicate a personal relationship with the covenantal God, and his people. This covenant created an indestructible link between God, the Father, and his people, his children. Nothing can break the bond of the covenant (cf. Byrne 2011:62). It gives meaning to the name Father, in the sense that God, as Father, has made a promise, a promise he will never break; a promise that will deliver his children from their suffering; a promise that includes the promise of his kingdom, as they are the heirs to his fortune. This longstanding promise inspires hope and comfort (cf. Byrne 2011:131) to any reader of these texts, to any child who calls God his or her Father. The name 'father' is also widely used in the book of Genesis; however, here it refers indirectly to the patriarch and the ancestors, rather than to YHWH directly. Byrne (2011:131) elaborates by stating that one can deduce from these texts the idea that God is stable and constant just as the forefathers, the generations who have lived before us.

Likewise, the idea of the unbreakable covenant is extended in the New Testament. Here Jesus reminded the early Christians, that because of God's unbreakable covenant, his relation to us as our father is also an unbreakable one (cf. Byrne 2011:62). This is highlighted in Galatians 4:6: and Romans 8:16.

In these passages the words 'children', 'sons of God' and 'adoption' emphasise how people became heirs to the kingdom of their Father, through the covenantal promise established in the Old Testament and extended through baptism in the New Testament. In essence these passages indicate that believers became co-owners of God's kingdom, along with Jesus (Grassi 1983:322), and even more so by calling the name 'Abba Father', they indicate their acceptance of this baptismal commitment to follow Jesus' example of complete obedience (cf. Byrne 2011:63).

Although some scholars disagree about the use of 'Abba' (in English translated as 'daddy'), Byrne (2011:60) affirms that the specific use of 'Abba' by Jesus referred to his own special relationship with God (Byrne 2011:60). Jesus was, however, not the only person to refer to God as Father, and it was not uncommon to do so. Nevertheless, Jesus commonly referred to God in this manner and encouraged all believers to do so (cf. Rm 8:15 and Gl 4:6) (cf. Bulkeley 2014:140-141). These two terms - 'Abba' and 'Father' - furthermore illustrates the picture of:

... an older, wiser figure who guides and offers comfort to the 'son' and, due to the assurance of their bond [...] the father will always look after the son and the son will always hold the father in a position of respect. (Byrne 2011:130)

\section{Traditional African religious discourses regarding God as Father}

Kombo (2007:178) states that African traditional religions regard God as the universal Creator - Father. Mbiti (1969:39) affirms this by saying that 'Over the whole of Africa, creation is the most widely acknowledged work of God'. According to Mbiti (1975:44), African traditional religions traditionally made use of various metaphors in referring to God as the Father, or the Creator, such as excavator, hewer, carver, originator, etc.

The fact that some tribes refer to God as Father during their prayers indicates that they do not only see him as the Creator of the world but also stand in a personal relationship with him, whereby they may communicate with God as Father as children who turn to their father in the time of need. Smith (1943:159) makes us aware that people who adhere to traditional African religions are very conscious of the authority of a father in their community and gives the example that Africans believe a good father will not withhold punishment to a child who did wrong.

\section{Our Lord, the King}

Through the narratives of the coresearchers, various discourses of God as King came to the foreground. In referring to God as King, they tended to call God, 'Lord', indicating his kingship. Manqoba states, 'I pray to my Lord God for protection, strength and hope so that this storm can just pass by'. Molimi included the following phrases in a poem that he has written, 'Lord Almighty help me once again', and 'I thank the Lord for what he has done in my life'.

Similarly most of the coresearchers made mention of God's almighty power in various ways, especially in determining the course of one's life. Here the idea of God's providence is prevalent, and their awareness that they live and breathe under God's providence. Manqoba states that he does not trust in fallible family structures, nor in the lack of responsibility of his father; rather he waits patiently upon the Lord to show him the way as he believes that God has a plan for him, but '... it's a bit tough right now, but I know I will get through it'. Manqoba also often made mention of the victory that he found in God. He says that for him life has been hard, but he believes in the victory that God has given him to overcome the worst, and that this victory will be the theme of his life. He knows that his victory will be in God.

The themes of deliverance and redemption are often made in reference to God the Lord. Molimi stated that sometimes, 
'I forget to thank the Lord for giving me strength and helping me to win against this storm'. Kgotoso sees God as his protector who gives him strength to overcome his problems. He states that God is aware of one's limits and abilities and that God has always rescued him, even when he thought that there was 'no way out'. Similarly, Molimi states that he irrevocably believes that:

God will help me face my Goliath because he will never leave me nor forsake me. I pray to my Lord God for protection, strength and hope so that this storm can just pass by.

The idea of obedience also runs concurrent with the idea of God as King and Lord. One of the coresearchers stated that one '... should obey and trust in God because we should seek him first and everything shall be given on to you'. Many of the coresearchers made it very clear that God expects them to obey him and his laws, because he is God, our Lord, who reigns over all. Molimi stated that he feels guilty because he trusts in God, but he does not always obey him.

In turn the theme of obedience seems to run concurrently with the image of God as Judge. The coresearchers' narratives conveyed the idea that of one does not obey God, one will be punished, or that God will withhold his blessings. Nevertheless, most of the coresearchers seem to perceive God as an almighty and just God, Who will punish sinful acts as he sees fit. In discussing the narrative ${ }^{5}$ of David, they stated that God has punished David rightly in letting his son die, as David did wrong in killing Uriah, the husband of Bathsheba (see 2 Sm 11:14-17), and had to be punished. Seemingly these coresearchers attribute God's actions to the prerogative of the God - God is God and purely because of this fact, God can do as he sees fit. This idea is supported by a coresearcher who states that God will judge over the bad and the evil one day because it is his 'job' and not ours.

A few of the coresearchers voiced the idea of God 'testing' his children. These tests seem to be aimed at determining a believer's trust and faith in God. Molimi said, 'God has tested me because he took my parents to see if I am strong enough to conquer death'. He believes that God has tested him by taking his mother away and now God expects him to trust in him and obey his commands. Likewise, some perceive God as testing people so that he can see how strong one is, '... not only physically but spiritually too' (Manqoba) and so that people can grow spiritually. It is not clear what they judge the fairness of these tests to be, seeing that these statements reveal a sense of ambivalence in their image of God as a fair and just God. It does however seem that they distinguish between punishment from God and God testing his child. Ambivalently, they never voiced any form of resentment towards God for testing their faith in this way, but instead they took their sadness and grief to God.

5.The narrative of David was used as analogue to bridge the gap between the story of the Bible and the story of the co-researchers. Refer to the article regarding the us of metaphors and analogues in narrative research: Loubser and Muller (2011) Discourses related to God as the Lord, our King from the
Old Testament and the New Testament and Judaic tradition

The word 'Lord' is defined as a title used by a man of high rank in the nobility, or who has been given the title 'lord' as an honour (Lea \& Duncan 2014). The name 'LORD' (in capitals) is used in the English Bible to replace the 'unpronounceable' name of God, YHWH (the tetragrammaton). This follows the Israelites' tradition of not pronouncing God's name out loud as it was too sacred to utter (cf. Braaten 1989:2). In Genesis 1:1 the name used for God is the name 'Elohim', which is the plural form of the name ' $\mathrm{El}$ '. Byrne (2011:27) states that ' $\mathrm{El}^{\prime}$ often denotes '... God's greatness or superiority over all other gods, such as "the great El"', while the plural of 'El', 'Elohim', magnifies the majesty of God and declares that God is the God of all gods (cf. Duck \& Wilson-Kastner 1999:15; Byrne 2011:28). Usually when the name 'Lord' (small letters) is used in the Old Testament it is translated from the word 'Adonai' (Hemphill 2001:20). When the names 'Lord God' appears, it is translated from 'Adonai $\mathrm{YHWH}^{\prime}$. These different names as used in the Old Testament emphasise God's personhood and his attributes aimed at glorifying and magnifying the name of God.

When looking at the New Testament use of the name 'Lord', it generally refers to the Greek word 'Kurios' translated into 'Master'. Hemphill (2001:20) postulates that the primary significance of the names Adonai and Kurios is that of ownership. These names emphasise that God is the rightful owner of everything and everyone and therefore he requires the worship and the obedience of all (cf. Hemphill 2001:22).

If we understand that the names of God, such as Lord, God Almighty, refer to God's lordship and sovereignty over the world, we can deduce that these names can be equated with his kingship. Although he is less often referred to as God, the King; naming him Lord, God, is implying that he is King the master, the owner of all things (cf. Hemphill 2001:24). Therefore when one reads the Old Testament and the New Testament, one is confronted with this image of God as the God, the Lord and the King.

When turning to the cultural context, we see that Israel, from the beginning of its existence as a nation, was a religious and moral community, ruled by God the Lord, YHWH. They were a theocratic nation - they had a bond with $\mathrm{YHWH}$ and swore allegiance to him (cf. Byrne 2011:38).

Furthermore, YHWH ruled by the Law that he established and gave to his nation. He administered justice '... in his name (Ex 22.28) and by his leadership of and his siding with Israel in its battles (Ex 14.14; 15.3; Nm 21.14; 1 Sm 18.17; 25.28)' (Byrne 2011:39). Likewise, it was a common belief in the ancient world that kingship pertained to the high god. Therefore in the royal ideologies of the day, the earthly king was the representative of the heavenly king, or this high god (Byrne 2011:39). Therefore, it can be concluded that God's sovereignty is his exercise of rule over his creation (cf. Grudem 1994:217). 
Inherent in the notion of kingship, as seen by the fact that YHWH ruled by the law that he himself established (Byrne 2011:39), is the idea that God as King is righteous and just. Erickson (1998:313) states that God's righteousness refers to the fact that the Law of God is as perfect as God himself, as the Law is an expression of his true nature. To say that God is righteous is to say that his actions are in accordance with the Law that he established, and therefore God can ultimately be trusted.

Where the righteousness of God indicates God's personal righteousness, his justice indicates his official righteousness, his actions of administrating his office according to it; and his insistence that other moral agents must adhere to these standards as well (cf. Erickson 1998:314). For God to be righteous and just at the same time, he has to administer his Law fairly, and impartially, condemning also those who were chosen as his representatives, but who disobeyed God's Law (cf. Erickson 1998:315). Therefore in the minds of the early Jews, God was King, ruler and Judge (Smith 1943:158).

Thus God is often viewed, or imagined as the Lord, the King and the Judge of all. What is striking however - and this can be seen in the narratives of the coresearchers - is that God's kingship is closely connected with the attribute of redeemer and deliverer. Therefore in seeing that the Lord $\mathrm{YHWH}$ is their King, the Israelites also acknowledged that he is their King, because he will deliver them. Byrne (2011:42) says that from the very beginning, Israel perceived $\mathrm{YHWH}$ as the deliverer, as the one who will liberate them from all hardships and tragedies. Byrne (2011:42) says, 'The perception of "redemption" in the Hebrew Bible takes its origins from the consideration of property and kinsman relations (Lv 25.26; Rt 4.4)' (Byrne 2011:42). Therefore Israel belonged to YHWH and as a result $\mathrm{YHWH}$ becomes involved in their everyday lives with the aim to deliver and redeem them (cf. Byrne 2011:42).

\section{Traditional African religious discourses on God as King}

Just as the ancient Jews thought of God as their King, many people who adhere to traditional African religions believe that God has power and control over all things - he is the Lord of life and death (cf. Smith, 1943:159) and is seen as the Giver - God gives life and other things as the Creator Father (cf. Mbiti 1970:75). It is never forgotten; though, that God is the one who gives, but he can also take away. This idea is clear in some of the traditional African religious expressions, such: 'He who gives and causes to rot' and 'the Giver who gives also what cannot be eaten' (Smith \& Dale 1920:199; Mbiti 1970:76).

In general, people who adhere to traditional African religions fear God and God's punishment if they break his Law (Smith 1943:177). This fear results from their great respect for God. Consequently, they refer to God as 'The owner of his things', indicating that '[C]ertain things are in His hands to do with as He is pleased to do' (Smith 1943:62).
Because God is seen as Ultimate Dispenser, Ruler and Judge, he is often associated with justice, retribution and punishment. As ultimate Judge, he has the right to '... give to each person his own portion, punishes those who commit wrong, and intervenes in human affairs' (cf. Mbiti 1970:76-79; Kombo 2007:179). Many people who adhere to traditional African religions belief that he will punish people individually through sending illnesses, natural disasters, misfortune, barrenness and even death, or on a global scale through natural phenomenon (Shapera 1937:59). In essence then, they understand God as a God of righteousness (cf. Smith 1943:68).

At the same time, God is seen as merciful and kind and he will exercise his will justly and fairly. God is always right and cannot ever do wrong (cf. Kombo 2007:176). God is seen as being holy and loving towards his people (cf. Mbiti 1969:37f.; Mbiti 1975:48-50; Kombo 2007:176); therefore, most people who adhere to traditional African religions consider God to be their Helper, their Saviour and Redeemer. Mbiti (1970:74) says that they often approach God for help, or attribute good fortune and help received in the time of need, to God (cf. Mbiti 1970:75). Forde (1951:160) recites an African saying 'God threads good and evil men on a single string'. This means that regardless of people's status and moral conditions, all people are entitled to receive God's help.

\section{God the Shepherd}

Contained in the narratives of the coresearchers is the need for God's guidance, through the embodiment of God as Shepherd. Some of the discourses associated with the other names of God seem to also apply to God as Shepherd.

Most of the coresearchers stated that they turn to God in times of need. They equate many of the Shepherd attributes to that which applies to God, such us saying that a Shepherd saves and protects his sheep when in danger, who looks for his sheep when they get lost, and who loves his sheep no matter what.

In sharing his story with the group, Molimi said that when he lived on the streets, God found him, saved him, reconciled him with his brother and showed him the 'right way'. He has faith that God will never leave nor forsake him, 'Give your best and God will do the rest'. Kgotoso supports this idea by saying that he puts all of his trust in God because God has been faithful to him in assisting him through his 'storms'. As a result of experiencing God's enduring love faithfulness and protection, he sees God as a Shepherd; he said, 'I was never naked or starving'.

When the coresearchers refer to guidance, they specifically point out that God shows one unto the right path or gives one direction, especially when one is 'lost'. Here the parable of the lost sheep comes to mind. The nature of God's guidance as shepherd seems to refer specifically to God inspiring them to be stronger (emotionally and cognitively), to have a better self-esteem and higher self-efficacy. Guidance also includes an aspect of teaching: God teaching 
them to follow in his ways: 'He guides me and makes me live a right life' (Manqoba); and another: 'he guides me in every way I take' (Molimi).

One also notices a sense of collective existence and comradeship in the name of God that appeal to the coresearchers. Manqoba said that he believes that God is on his side and that God will help him to stand on his '... own two feet again'. Here it seems if many of the coresearchers have found a place to belong, being part of God's 'flock'.

One common denominator in the stories of the coresearchers is the sense of hope. This sense of hope seems to be founded on the idea that God will not abandon them - they might not escape all hardships and struggles, but they will endure through it with God by their side. In God as Shepherd, they find a promise, a promise of his presence; a promise that God will never forsake them and a promise that never again, will they be orphaned. This promise fills them with hope for the future; it provides them with a reason to continue with life even though the road might be rocky. In God as Shepherd they believe that he will never forsake his flock.

\section{Biblical discourses related to God the Shepherd}

The word 'shepherd' occurs quite frequently in scripture and is sometimes replaced by the word 'pastor'. Generally, this word is used to represent the type of relationship that a ruler has with his people or, more specifically, the relationship God has with his people (cf. Easton 1894).

McFague (1982:135) comments on this model for God as presented in Psalm 23, by saying that '... the tone of the entire Psalm is not one of sheep like ineptitude, but rather of profound gratitude for divine solicitude and comfort. The principle model is the Lord as "shepherd", not people as "sheep"'. She makes us aware that the characteristics associated with the shepherd model are similar to the maternal characteristics associated with God. These characteristics include renewal, comfort, physical nurture, care, guidance and compassion. Furthermore, this 'model' also relates to the liberator model we find in the New Testament, which focuses on relief, liberation and redemption (McFague 1982:135).

The redescription of God through Psalm 23 reveals God as a caring and loving Shepherd who is involved with three main activities: (1) provision, (2) guidance and (3) protection. One immediately becomes aware that these qualities are shared with the name of God the Father and God the King. The experience of God as Shepherd seem to strongly relate to the covenantal promise as understood in the Old Testament.

\section{Traditional African religious discourses on God the Shepherd}

People who adhere to traditional African religions often refer to God as their 'Pastor', which conveys two inherent actions: (1) that of shepherding and (2) that of teaching. According to some, God assists people in times of need, but also teaches them in the '... various arts of living' (Mbiti 1970:75). God is the Wise one; therefore, only God can show one the right way (cf. Mbiti 1970:3). It seems however that it is not common for African religious people to directly refer to God as Shepherd.

\section{Pictures of God through Jesus}

Not once in the narratives of the coresearchers did they ever refer to the person of Jesus. The researcher found this peculiar and set about in searching for underlying discourses that could inform her understanding of this gap in their spiritual narratives. It soon became clear that although direct mention of Jesus is never made, the different attributes associated with the specific names of God could be linked with the attributes of God, proclaimed through the personhood of Jesus. One such attribute, consistently found through all the names of God, is God's unfailing love for them. God's love seems to be the framework for looking at God's actions and thereby understanding God. It seems as if God's love is perceived as the motivation behind his interaction with his children. The coresearchers stated unanimously that Gods' love makes them stronger and gives them hope in facing the various challenges posed by life. Another coresearcher reiterates this by saying that God has proved his love for him by being faithful to him, supporting him through the challenges and being loyal in protecting him.

From this it is concluded that the coresearchers' interaction with the Gospels enhanced their religious language and influenced the way that they view God, understand God, and subsequently, name God, as the love of God is the prevailing theme throughout the New Testament. Ricoeur (1979) supports this phenomenon and states that we can know God because he made himself known through Jesus, he says:

... Jesus' humanity is not thinkable as different from his vision with God. Jesus of Nazareth cannot be understood apart from god, apart from his God, who is also the God of Moses and the prophets. (p. 224)

Although the doctrine of God is not the primary theme of the New Testament, the central aim of Jesus' preaching was to reveal the character of God and what that character meant to the individual being (cf. Stanton 2010; Winters 2002; Byrne, 2011:49). People got to know God through Jesus and specifically through the circumlocutions used by Jesus in the New Testament (cf. Byrne 2011:48).

Although the New Testament is reserved in its use of language that refers to God, it is clear that the authority of the narratives told by Jesus rests on the authority of God; the God whose Kingdom Jesus proclaims (cf. Hurtado 1992:279; Byrne 2011:48). Byrne supports this by saying that in the New Testament, Jesus is depicted as the representative of the Holy God, in his being of being fully human, and also divine, he conveys God's message on his behalf (cf. Byrne 2011:50).

In support of the coresearchers who extracted their images of God from the personhood of Jesus, Braaten (1998:9) states that people, in receiving the gospel, tend to translate the 
message of God as to integrate it with their own context. During this integration process, the name of God is often changed, indicating a personal understanding of God. Therefore, a positive symbiosis takes place between the gospel of Jesus, culture and context, showing how the name of Jesus has universal implications for the experience of God.

\section{Maternal attributes inherent in the Image of God}

On the idea of God as Mother, it should be stated that although the New Testament never refers to God in female or maternal instances, Jesus nevertheless often described the Father-God relationship in terms, not common of the culture of the day (cf. Bulkeley 2014:144). Bulkeley (2014:144-145) refers to many examples in the New Testament where Jesus refer to God as Father, but in his parables or stories, many of the characteristics attached to these pictures are those culturally attributed to the mother.

This is significant because although the coresearchers commonly refer to God as their Father, many of the qualities they associate with the name, also corresponds to qualities that are traditionally seen as maternal ${ }^{6}$, such as care, nurture, love and compassion. Similarly, in their discussion of God as Shepherd, more maternal qualities became evident. Being careful in making assumptions, one might perhaps hold that the paternal concept of God as father is not set in an image of gender. Thus God as Father is the only father where when one mentions the father, a mother is not naturally implied. Perhaps, in this case, the maternal characteristics inherent in parenthood are taken up by the metaphor, or model, of Father and Shepherd.

Perhaps the question should rather be, 'Is the concept of "father" more significant and meaningful to them, in their lived context, than the concept of "mother"?' At first glance, it would seem to be so indeed, as many of them stated that they have found a Father in God, in the absence of their own biological father. With further enquiry, however, the qualities they attribute to God as Father seems to be the primary reason why they feel attached to God. These qualities include the fact that God loves them, protects them, guides them, cares for them, nurtures them and disciplines them in love. Perhaps they attach these qualities to the personhood of father, per religious instruction, and not just because the concept 'father' itself has become the embodiment of the qualities of God. Perhaps God as Father is one way of understanding God - but God is not limited to the gender of the image.

\section{Conclusion: Deconstructing the discourses inherent in the names of God}

It is clear from the narratives of the coresearchers and the names they use to subsequently refer to God that their understanding of God originated from multiple sources and 6.Take note that these qualities are not exclusively maternal, but also not exclusively paternal. resulted from cross-contextual, cross-cultural, cross-religious and interdenominational interaction, with people and text.

It became evident that the name 'Father' for God is a popular way to refer to God, and subsequently, to think about God, for both the coresearchers and our ancient forefathers. Perhaps the image of God as father provides the coresearchers with the same sense of stability and constancy as for the ancient Jews, as God was the Father for Abraham, Isaac and Jacob and will be forever a reliable and trustworthy father to them. It would seem that the coresearchers find solace in the promise contained in the name of the Father, a promise of protection, provision and guidance - a promise evident from reading the narratives in the Bible. Furthermore, as for the people of both the Old Testament and the New Testament, the coresearchers seem to also feel 'adopted' through the bond of the covenant, sealed by the commitment of the baptismal rite. They have found a home in God, a place to belong, where they will always be loved, be sheltered, be clothed and fed and be protected from the storms outside. They trust God ultimately to care for them as a father cares for his children.

It does not seem as if the coresearchers' experience and perception of God as father is strongly linked with the traditional African religious perception of God as father. Although believers pray to a personal Father-God and turn to the Father for guidance (which the coresearchers also do), it seems as if their perception of God as Father is more closely linked with the idea that God created everything and therefore he has fathered the creation. The consequence of this perception is that God created and then retreated, only to be contacted in extreme cases.

The coresearchers' understanding of the Father-God is much more closely related to the biblical understanding of the promise contained in the covenant and in baptism; that God has accepted us as his children, and therefore we share in his Kingdom as heirs. He will therefore protect us and provide for us as a father does and we can call upon him on a daily basis.

At the same time they have the understanding that they as children must obey God, and if they do not, God will discipline as he sees fit. They seem to understand this kind of discipline as originating from God's unfailing love for them. This model of God as Father is evident throughout the stories contained in the Bible.

The second name for God that strongly relates with the model of father is the idea that God is our Shepherd. The narratives of the coresearchers conveyed the idea that they approach God as Shepherd when they seek solace and when they have a need for guidance and direction. As seen from McFague (1982:135) explanation of Psalm 23, there is no doubt in our minds that the writer of the Psalm and Jesus himself wanted to convey a strong message related to the image of God as Shepherd. This message conveys the idea to the coresearchers that God as our Shepherd will provide, will guide and will protect (cf. McFague 1982:135). 
This message is found undoubtable, directly and indirectly deduced, throughout the stories of God with his people. It is also clear that God is seen as a kind of pastor in the paradigm of traditional African religion. According to their understanding God, as Pastor, is mainly involved in teaching and guiding his children. Even today, teaching and shepherding are important concepts in the mind of people who adhere to traditional African religions. Elders, traditional healers, ancestors and inevitably God are constantly approached for guidance (cf. Mbiti 1970:229). Additionally, people who adhere to traditional African religions generally have several initiation ceremonies which focus on teaching the newcomer (e.g. boy, girl) in the ways of the practice (marriage, manhood, womanhood, parenthood etc.). It might be stated that because the coresearchers lacked a father, a teacher, a male role model, that God as Father and as Shepherd filled this void in their lives and that they turned to God and the teachings about God (through biblical teaching and oral stories distributed amongst believers) to be their heavenly Father and Shepherd.

An idea shared by the images of Father and Shepherd is the idea of God as a shelter. God becomes a safe haven for hiding from the storms outside - when hurt, when abandoned and when lost, one can return to God as Father (as in the parable of the prodigal son) or God as Shepherd will search for you, until he finds you (as in the parable of the lost sheep). When back, safe in the loving and graceful arms of God, God will comfort. This is an image specific to the image of God as Father and Shepherd found in the Bible.

Finally, we have seen that God is often viewed as the Victor, the Ruler, the King and the Lord, who, in his capacity of his lordship, will judge as he sees fit. Similarly, we have seen that the idea of God as King is prevalent in both the biblical literature, as well as in the African religion. The coresearchers conveyed their awe and respect for God as the almighty God who have created, who beholds and who at the end will judge our fate. This seems to bring comfort that in a sense God will judge over the injustice they experience here on earth. Similarly, however, we see the idea that God will also punish them if they disobey him, or that he will withdraw his favour and presence. This idea is found consistently in the literature explaining the beliefs of traditional African religion and coincides with the beliefs of the coresearchers. This belief, however, does not adequately explain why the coresearchers think that God tests them by taking their loved ones away. Further research into this idea will be done and discussed in a follow-up article.

Additionally, the coresearchers seem to find solace in the embodiment of God as King, that God rules over all, and therefore knows more and sees more than we do. As a Kingly Father, he knows what is best for his children.

The references contained in the narratives of the coresearchers give some insight into their 'pictures' of God, and how these pictures influence their relationship with God. These three 'pictures' seem to not function in a linear fashion, where they are separated by the boundaries of the characteristics entailed in each name for God. Rather they seem to be complimentarythe one image feeds into the next. Isaiah 40:10-11 gives a good example of this:

10 Behold, the Lord God comes with might, and his arm rules for him; behold, his reward is with him, and his recompense before him.

11 He will tend his flock like a shepherd; he will gather the lambs in his arms; he will carry them in his bosom, and gently lead those that are with young.

Bulkeley (2014:147-148) shows how the above text brings the two pictures of God together - one as mighty conquer and the other as a tender shepherd. Here the prophet gives us a glimpse of the multiple facets contained within the images of God: 'God is indeed a powerful conquering king; but God is, at the same time tender and gentle, like someone cuddling a lamb' (Bulkeley 2014:148). He rightly notes that a single picture of God alone will not to do justice to God in his totality.

It is therefore clear that the pictures we have of God, motivate the specific names we choose to represent our relations with God and tell us something about our understanding of and relationship with God. McFague (1982) speaks of the models we have for God and says that it does not only function in redescribing God, so that we can understand God; but it also redescribes our understanding of the image used. Therefore, these images contained in the names that we give God become a model for life and relation with God (cf. McFague 1982:135-136).

We conclude that much of the coresearchers' manner in which they refer to God might have been the result of religious pedagogical instruction, founded in the text of both the Old Testament and the New Testament, and also from oral narratives carried over from traditional African beliefs and culture. It seems if these teachings and the sharing of narratives and beliefs with significant others, combined in a unique way with the coresearchers' personal experience of God, to produce their unique understanding of God. It also makes us aware of the profound influence of the Gospels in relaying subtle, but dynamic images of God, which acts as 'roadmaps' to understanding the character and the will of God. Also, these stories raised our awareness that religion can never be applied outside the context of culture. The combination of these influences resulted in a special and personal relationship with the one they call their Father, their Shepherd and their King.

In the use of different names for God, Byrne (2011:52) reminds us that irrespective of the specific names we call God, at the end our reference to God must benefit our own understanding of that God - we are limited by our language - and by acknowledging this, the name we choose to represent the qualities inherent in God must in essence aid our personal relationship with God, by assisting us to grasp the idea of God. 


\section{Acknowledgements Competing interests}

The author declares that she has no financial or personal relationships which may have inappropriately influenced her in writing this article.

\section{References}

Boylorn, R., 2008, 'Participants as co-researchers', in L.M. Given (eds.), The Sage encyclopedia of qualitative research methods, pp. 599-601, Sage Publications, Los Angeles.

Braaten, C.E. (ed.), 1989, Our naming of God: Problems and prospects of God-talk today, Fortress Pr, Minneapolis.

Buber, M., 1994, Scripture and translation, Indiana University Press, Bloomington, IN.

Bulkeley, T., 2014, 'Jesus and the Father', Asian Journal of Pentecostal Studies 17(2), 139-150.

Byrne, M., 2011, The names of God in Judaism, Christianity, and Islam: A basis for interfaith dialogue, 1st edn., Bloomsbury Academic, London and New York.

Demasure, K. \& Müller, J.C., 2006, 'Perspectives in support of the narrative turn in pastoral care', Nederduitse Gereformeerde Teologiese Tydskrif 47(3), 410-419.

Duck, R.C. \& Wilson-Kastner, P., 1999, Praising God: The trinity in Christian worship, Westminster John Knox Press, Louisville, KY.

Easton, M., 1894, 'Eastons Bible dictionary online', in Bible study tools, viewed 25 June 2015, from http://www.biblestudytools.com/dictionaries/eastons-bibledictionary/

Erickson, M.J., 1998, Christian theology, 2nd edn., Baker Academic, Grand Rapids, MI.

Forde, D. (ed.), 1951, The Yoruba-speaking peoples of South-West Nigeria, International African Institute, London.

Foster, D., 2004, Liberation psychology in self, community and psychology, UCT Press, Cape Town.

Grassi, J., 1983, 'Abba, Father (Mark 14:36): Another approach', Journal of the American Academy of Religion, 50, 449-458.

Group discussions and Interviews, Tree of Life camp, 10-12 October 2008, Sikelele Camp site, Magaliesburg.

Group discussions and Interviews with co-researchers, Tree of Life camp, 26-28 February 2010, Sikelele Camp site, Magaliesburg.

Grudem, W.A., 1994, Systematic theology: An introduction to biblical doctrine, InterVarsity Press, Nottingham.

Hemphill, K.S., 2001, The names of God, B\&H Publishing Group, Nashville, TN.

Hurtado, L., 1992, 'God', in J.B. Green, S. McKnight \& I.H. Marshall, (eds.), Dictionary of Jesus and the Gospels, p. 315, IVP Academic, Downers Grove, IL.
Kombo, J.H.O., 2007, The doctrine of God in African Christian Thought: The holy trinity, theological hermeneutics and the African intellectual culture, BRILL, Leiden.

Lea, D. \& Duncan, R., 2014, Oxford learner's dictionary of academic English, Oxford University Press, Oxford.

Loubser, J., 2010, 'The spiritual and psychosocial gender specific stories of adolescent orphans affected by HIV and AIDS, in the absence of a Father Figure: A postfoundational practical theological approach', PhD thesis, Dept. of Practical Theology, University of Pretoria, Pretoria.

Loubser, J. \& Muller, J.C., 2011, 'The use of metaphors in Narrative Research in exploring and describing experiences of adolescent male orphans affected by HIV and AIDS', HTS Teologiese Studies/Theological Studies 67(2), Art. \#1009, 9 pages.

Mbiti, J.S., 1969, African religions \& philosophy, Praeger Publishers, New York.

Mbiti, J.S., 1970, Concepts of God in Africa, Praeger Publishers, New York.

Mbiti, J.S., 1975, Introduction to African Religion, Heinemann Educational, London.

McFague, S., 1982, Metaphorical theology: Models of God in religious language, Fortress Press, Minneapolis, MN.

Meyer, J., 2013a, 'Adolescent male orphans affected by HIV and AIDS, poverty and fatherlessness: A story of marginalisation?', HTS Teologiese Studies/Theological Studies 69(1), Art. \#1932, 10 pages. http://dx.doi.org/10.4102/hts.v69i1.1932

Meyer, J., 2013b, 'Deconstructing masculinity: Dominant discourses on gender sexuality and HIV and AIDS from the experience of the adolescent male orphan', HTS Teologiese Studies/Theological Studies 69(1), 12

Meyer, J., 2014, 'Development of alternative interpretations: The story of an orphaned boy affected by HIV and AIDS and father abandonment', Verbum et Ecclesia 35(2), 13.

Müller, J.C., 2005, 'A postfoundationalist, HIV-positive practical theology', Practical Theology in South Africa 20(2), 72-88.

Ricoeur, P., 1979, 'Naming God', Union Seminary Quarter Review, 34, 15-27.

Shapera, I., 1937, The Bantu-speaking tribes of South Africa: An ethnographical survey, Maskew Miller Limited, Cape Town.

Smith, E.W., 1943, African beliefs and Christian faith : An introduction to theology for African students, evangelists and pastors, United Society for Christian Literature, London.

Smith, E. \& Dale, A.M., 1920, The Ila-speaking peoples of Northern Rhodesia, Macmillan and Co., London.

Sosckice, J., 2002, 'Philo and negative theology', in M. Olivetti (ed.), Theologie negative, Biblioteca dell'Archivo di Filosofia, Padova.

Stanton, J., 2010, 'Seismic shift in seminary education', in Inter-religious studies, viewed 25 June 2015, from http://irdialogue.org/articles/seismic-shift-inseminary-education-by-joshua-stanton/

Van Huyssteen, W., 1999, The Shaping of Rationality: Towards interdisciplinarity in Theology and Science, Eerdmans Publishing Company, USA.

Winters, J., 2002, 'Why we fear the unknown', in Psychology Today, viewed 25 June 2015, from http://www.psychologytoday.com/articles/200305/why-we-fear-theunknown

Young, W.W., 2007, The politics of praise: Naming God and friendship in Aquinas and Derrida, Ashgate Publishing, England. 